YEARBOOK

of ANTITRUST

and REGULATORY

STUDIES

www.yars.wz.uw.edu.pl
Peer-reviewed scientific periodical, focusing on legal and economic issues of antitrust and regulation. Creative Commons Attribution-No Derivative Works 3.0 Poland License.

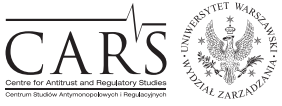

Centre for Antitrust and Regulatory Studies, University of Warsaw, Faculty of Management www.cars.wZ.uw.edu.pl

\title{
Consensual Dispute Resolution in the Damage Directive. Implementation in CEE Countries
}

\author{
by \\ Małgorzata Modzelewska de Raad*
}

\section{CONTENTS}

I. Introduction

II. Consensual dispute resolution - definition

III. Application of competition law in arbitration - overview

IV. Consensual settlement of claims resulting from infringements of competition law - advantages

V. Directive's 'carrots' to enhance consensual resolution

1. Suspension of the statutory limitation

2. Suspension during the court proceedings

3. Modification of the settling infringer's liability in multi-party cases

4. Compensation as a fine mitigating factor

VI. Implementation of the Directive in the area of consensual resolution in CEE countries

VII. Claiming damages resulting from an infringement of competition law in a consensual way vs state court - post-Directive

VIII. Conclusion

\section{Abstract}

This paper discusses the use of consensual dispute resolution for the purpose of antitrust damage claims as introduced by the Directive. It presents these type of claims in a broader context of arbitration (or ADR), in comparison with traditional claim settling before a state court. Particular focus is on selected CEE countries and their implementation of the Directive, serving as an example of the transposition

* Attorney and co-founder at Modzelewska \& Paśnik Law Firm, Warsaw, Poland; e-mail: malgorzata.modzelewska@modzelewskapasnik.pl; Article received: 25.07.2017, accepted: 01.09.2017. 
of the Directive's rules (Article 18 and 19) into national systems in the area of consensual dispute resolution. Specific institutions intended to encourage consensual resolution included in the Directive (and transposed into national systems) are being commented on as well. Lastly, the paper briefs on the advantages of ADR in general, and concludes that even post-Directive, ADR remains attractive as a complimentary instrument to public enforcement and state judiciary enforcement.

\section{Résumé}

Cet article discute de l'utilisation du règlement consensuel des litiges dans le cadre des actions en dommages pour les infractions aux dispositions du droit de la concurrence introduites par la Directive. Il présente ce type des demandes dans un contexte plus large d'arbitrage (ou modes alternatifs de résolution des conflits «MARC»), en comparaison avec des demandes traditionnelles devant les tribunaux nationaux. Un accent particulier est mis sur certains pays d'Europe centrale et orientale et leur mise en œuvre de la Directive, qui donnent l'exemple de la mise en œuvre des règles de la Directive (articles 18 et 19) dans les systèmes nationaux de règlement consensuel des différends. Des institutions spécifiques destinées à encourager la résolution consensuelle incluses dans la directive (et transposées dans les systèmes nationaux) sont également commentées. Enfin, l'article décrit les avantages du MARC en général et conclut que même après la mise en œuvre de la Directive, le MARC reste attractif en tant qu'instrument complémentaire à l'application publique et à l'application judiciaire du droit par les États.

Kew words: private antitrust enforcement; arbitration; competition law arbitration; Damages Directive.

JEL: K21; K42

\section{Introduction}

In principle, any damage caused in connection with a commercial activity could be settled either within a framework of institutional dispute resolution, such as arbitration or mediation, or simply through either bilateral, or multilateral negotiation(s) and settlement(s) between the interested parties. Damages caused by infringements of competition law are no exception. Moreover, there are several reasons to believe that consensual resolution could be extremely suitable for effective damage claims which resulted from infringements of competition law. This belief was obviously shared by the drafters of Directive 2014/104/EU ${ }^{1}$

1 Directive 2014/104/EU of the European Parliament and of the Council of 26.11.2014 on certain rules governing actions for damages under national law for infringements of the 
who created several instruments to encourage the settlement of the claims in question in alternative ways. Those instruments have been already transposed in a number of Member States into their national systems, ${ }^{2}$ including Estonia, Hungary, Poland, Romania, Slovakia, and Slovenia; in the remaining CEE jurisdiction, the said instruments are awaiting implementation.

This paper discusses first: the legal background of claims with a competition law element in ADR (and in particular - in arbitration); second: advantages of this type of dispute resolution, third: institutions in the Directive that relate to consensual dispute resolution, and fourth: transposition of the Directive's institutions in selected CEE countries. Lastly, the paper addresses impact of the 'facilitations' introduced in national systems (as a result of the Directive's transposition) on the attractiveness of consensual dispute resolution for this type of claims.

\section{Consensual dispute resolution - definition}

There are a number of possible definitions of 'consensual dispute resolution'. Often, the term is regarded as equivalent to the popular term 'alternative dispute resolution' ('ADR'), which is used for any form of claim settlement outside the state judiciary. However, these terms are not synonyms. Apparently, ADR is meant for any form of out-of-court resolution when the parties decide to resolve their dispute with a help of a third person (expert, mediator, arbitrator); meanwhile, 'consensual dispute resolution' shall be understood broader, including dispute resolution with, or without any institution or person supporting the resolution of a given dispute (Idot, 2010, p. 51-52). Equally, the Directive's drafters intended to cover all forms of formal or informal processes that lead to the settlement of claims. The Directive's definition (point 21) explains that 'consensual dispute resolution' means any mechanism enabling parties to reach the out-of-court resolution of a dispute concerning a claim for damages'.

Thus, the term used in the Directive, and to be implemented into national legal systems, shall be understood broadly. As recital 48 of the Directive further explains, it shall cover 'arbitration, mediation or conciliation'; the same term shall be used for an agreement made in the course of ordinary

competition law provisions of the Member States and of the European Union, OJ L 349, 05.12.2014.

2 As of 14 June 2017, 20 countries reported to the Commission their implementation of the Directive, see: ec.europa.eu/competition/antitrust/actionsdamages/index.html (retrieved 14.07.2017). 
court proceedings and brought before the court in order to be provided with enforceability under state enforcement measures. It may also invoke an ordinary negotiation between the parties covered in a simple agreement that will never be the subject of any state enforceability mechanisms.

Qualifying parties' conduct as 'consensual dispute resolution' makes them benefit from the attractive solutions set out in the Directive, such as suspension of limitation period or reduction of the total claim amount (discussed below in more detail). The practical problem the parties shall take care of - so that they do not lose the benefits in question - is to sufficiently record their 'consensual dispute resolution', if the process is outside any formalised proceedings or institutions and has a totally 'private' nature. It may become necessary to evidence that the parties indeed 'engaged in consensual dispute resolution' (see recital 50) as well as the time when they have effectively done so.

Obviously, if the parties get involved in arbitration or mediation and follow certain procedure, the process is by its very nature recorded beyond any doubt.

Lastly, despite the fact that in many jurisdictions arbitration has the benefit of state enforceability (through recognition or enforceability procedures), arbitration is by no means deprived of its 'consensual' nature, and definitely falls under the notion of 'consensual dispute resolution'.

\section{Application of competition law in arbitration - overview}

Arbitration is the most popular way to settle the dispute outside the state judicial framework. Its role has been noted in both: commercial disputes with a competition element, as well as in damage actions, ${ }^{3}$ despite lack of engagement of EU institutions or recognition in the relevant statute on the EU level (Szpunar, 2010, p. 615).

Notably, an arbitration tribunal is not recognised as a 'court' under the TFEU, ${ }^{4}$ which may impair effective and equivalent application of EU competition law by those tribunals, as they are deprived of the privilege to turn to the Court of Justice with a preliminary question on the interpretation of European law.

The issue of the application of competition law has been answered in the Court of Justice's ruling in Eco Swiss. ${ }^{5}$ In this preliminary ruling, the Court of

3 OECD report (2010), Arbitration and Competition, http://www.oecd.org/competition/ abuse/49294392.pdf (retrieved 14.07.2017).

${ }^{4}$ See: judgment of 23.03.1982, Case C- 102/81 Nordsee v. Reederei Mond, ECLI:EU:C:1982:107.

5 Judgment of 1.06.1999, Case C-126/97 Eco Swiss China Time Ltd. v. Benetton International NV, ECLI:EU:C:1999:269. 
Justice held that competition law forms part of public policy of any Member States and the EU. There are two important conclusions stemming from such a qualification: first, whenever the law applicable to the dispute is the national law of an EU Member State, competition law applies, and second, whenever the law applicable in recognition or enforcement of arbitration award proceedings is the national law of an EU Member State, competition rules (domestic or European) will also apply. Importantly, the challenge of the arbitration award takes place in the country of the place of arbitration, which means that if the lex for is EU Member's law, naturally the award shall take account of these rules.

Since the article's focus is not to discuss the application of competition law in general (all the interesting issues of the application of competition law before the judiciary and in arbitration are discussed specifically by Derains, 2001, p. 323 et seq), it is sufficient to conclude that the arbitrators, even if they would be ruling under fairness rules, may not disregard competition law since they should anticipate post-arbitral proceedings and take care of thefull enforceability of their judgment. This is exactly what was also confirmed by CJEU in Almelo. ${ }^{6}$

In short, competition law is a mandatory public policy regulation, which shall be applicable in arbitration proceedings. ${ }^{7}$ In any case, arbitral tribunals need to foresee proceedings for the setting aside of the award (or for making it enforceable by state institutions), and equally take account of these regulations when deciding a case with a competition law component. Further, national courts, when engaged in aforementioned proceedings, are under the duty to apply EU law (or any relevant Member State's law) in order to give effect to the principles of equivalence and effectiveness ${ }^{8}$ under Article 19(1) TFEU. National courts may also make use of the instruments provided under Regulation 1/2003 in order to ensure uniform application of EU competition law.

Up-to-date practice indicates that also the cooperation between arbitration tribunals and the European Commission is permitted and practically possible, in view of effective and equivalent application of EU competition law. ${ }^{9}$ It

6 Judgment of 27.04.1994, Case C-393/92 Almelo, ECLI:EU:C:1994:171.

7 The question remains whether it should be taken into account ex officio or if it should be always called by either party; to follow on this discussion, please see Derains, 2001, p. 323 et seq; according to Tomáš Pavelka, the courts apply competition law ex officio, see: Pavelka, 2012, p. 10.

8 Please see the detailed comparison of the application of the principles vs national procedural autonomy (to be duly noted when discussing the principles of equivalence and effectiveness) by Petit, 2014.

9 See the Commission's interventions in: 1) Ioan Micula, Viorel Micula and others v. Romania, ICSID Case No. ARB/05/20; 2) AES Summit Generation Limited and AES-Tisza 
is also highly advisable for National Competition Authorities (hereinafter, 'NCAs') to work out ways to invite an arbitration tribunal to ensure that once a competition law infringement becomes the key for a given arbitral ruling, they may consult a NCA or the European Commission.

Now, since the arbitrability of competition law is established, there is no doubt that cases involving damages caused by competition law infringements can also be settled in arbitration.

There could be two grounds to refer such a case to arbitration. One is when a party to a contract infringes competition law, and the claim indicates sufficient liaison with the contract to rely on the arbitration clause, or - two - when the parties, in view of the existing claim, agree to settle the case before an arbitral tribunal (arbitration agreement). While the latter is rather undisputable, there is a vivid discussion about to what an extent parties may rely on the arbitration clause in antitrust damage cases. The discussion is well nourished by various jurisprudence on this issue. On one hand, it seems that Dutch and Finish courts find that broadly worded arbitration clauses do not cover damage claims, ${ }^{10}$ on the other hand, an English court has recently accepted, in the Microsoft v. Sony Europe case, ${ }^{11}$ the applicability of the arbitration clause. In the dispute, Microsoft claimed damages against Sony Europe as jointly and severally liable for a damage caused by an alleged cartel involving Sony, Samsung and LG. To give effect to the arbitration clause, the High Court decided to stay the proceedings. Interestingly, the English High Court built upon the CJEU's views in CDC Hydrogen Peroxide SA v. Akzo Nobel NV et al., ${ }^{12}$ that actually left the issue of arbitrability of antitrust damages' claims undecided, by stating: 'The effectiveness of broadly worded agreements to arbitrate in relation to follow-on damages claims (...) subject to uncertainty in Europe'. According to the English High Court, 'I can see nothing in the decision of the Court to require me to displace the effect of the arbitration clause as something inimical to EU law'. ${ }^{13}$

Erömü Kft. v. Republic of Hungary, ICSID Case No. ARB/07/22; as well as the ICC cases listed in: Kolber, 2012, p. 67-81.

10 Judgment of the District Court of Amsterdam of 04.06.2014, CDC Project 13 SA v. Akzo Nobel NV et al., Case No. C/13/500953/HAZA 11-2560 (upheld by the Amsterdam Court of Appeals); judgment of the District Court of Central Netherlands of 27.11.2013, East West Trading BV v. United Technologies Corp. and Others; judgment of the District Court in Helsinki of 04.07.2013, CDC Hydrogen Peroxide SA v. Kemira Oyj. All the jurisprudence listed herein is cited by: Živković, 2017.

11 Judgment of the English High Court of 28.02.2017, Microsoft Mobile OY (Ltd) v. Sony Europe Limited et al., No. EWHC 374 (Ch).

12 Judgment of 21.05.2015, Case C-352/13 CDC Hydrogen Peroxide SA v. Akzo Nobel NV et al., ECLI:EU:C:2015:335.

13 Judgment of the English High Court of 28.02.2017, Microsoft Mobile OY (Ltd) v. Sony Europe Limited et al., No. EWHC 374 (Ch), para 81. 
Definitely the issue requires in-depth analysis. For the purpose of this paper, one shall conclude that European jurisprudence (in various EU jurisdictions) is not uniform on the effectiveness of arbitration clauses in antitrust damage disputes. Those who concur with the view that broadly drafted arbitration clauses shall apply (see also Aren Goldsmith's argument that overpayment for goods resulting from a cartel could be qualified as failure to perform the contract in Goldsmith, 2015) to disputes arising out of a damage caused by an antitrust violation, call the US example ${ }^{14}$ as well as well-establishes continental doctrine on the arbitrability of various tortious claims. ${ }^{15}$ The Directive's drafters' belief in arbitration (seen as a key method of consensual dispute resolution) expressed in a few of its articles, gives hope for a (more) friendly approach to arbitrating antitrust damage claims in the future.

\section{Consensual settlement of claims resulting from infringements of competition law - advantages}

Claiming damages resulting from a competition law infringement is a hazardous business. First, the opposing parties may still hold a commercial relationship, and for obvious reasons, it may turn extremely difficult to file a law suit against an existing supplier. Second, even if the parties do not trade any longer, the infringer would usually get hostile against the claimant since most likely he had already 'paid his bill' to a NCA or the European Commission. In such circumstances, what brings the parties to conciliatory resolution are (still) tangible mutual benefits making the parties willing to settle the case amicably, instead of arguing it before a state court.

The first advantage a prospective defendant may see is the confidentiality of arbitration. Compared to a public hearing and easily accessible information

14 JLM Industries, Inc. v. Stolt-Nielsen SA, 387 F.3d 163 (2d Cir. 2004).

15 'German Federal Supreme Court, judgment of 24 November 1964 - VI ZR 187/63. Similarly, the Greek Supreme Court held that where the same facts simultaneously amount to a breach of contract and a tortious act, the latter fall within the scope of an arbitration clause that refers to '[a]ll differences arising in relation to the present contract' (Greek Supreme Court judgment no 506/2010). Regarding an arbitration agreement referencing 'all disputes arising out of a contract', the Austrian Supreme Court deemed the agreement applicable'as long as the (concretely) damaging behaviour and a breach of contract are, in the narrowest sense, one event' (cf. Austrian Supreme Court - 4 Ob80/08f, 26 August 2008). The English High Court deemed an arbitration clause for 'all disputes from time to time arising out of this contract' to encompass claims in tort (cf. Aggeliki Charis Compania Maritima SA v. Pagnan SpA (The Angelic Grace) [1994] 1 Lloyd's Rep. 168, 174 (QB)), cf. also X Ltd v. Y Ltd [2005] EWHC 769 (TCC)' - the jurisprudence and laws cited by Bellinghausen and Grothaus 2015. 
on the case decided before a state court, the defendant may wish to keep his arguments and agreed amount of damage secret (at least for some time). Thus, in cases where a defendant anticipates many possible claims, his pressure on amicable settlement may raise.

Second, both parties may seek this way to settle in order to resolve an uneasy situation quicker. Usually, arbitration or mediation tends to lead to receiving an award much faster than it is usually done before a state court.

Third, the parties may simply feel much more comfortable with a set of authorities of their choice deciding their case. The usual fear that difficult issues of competition law or damage liability may lead to unexpected results before state courts shall disappear in arbitration. Each party may chose at least one arbitrator and may have impact on the selection of a presiding arbitrator. In mediation, both parties usually agree on one mediator. If they discuss the matter informally, they may bring experts (including economic experts) of their choice who may put forward their calculations and come to a reasonable figure, to the satisfaction of both parties. The advantage of having greater control over how the proceedings progresses is a valuable asset of consensual dispute resolution as well.

Fourth, a defendant coming to settle amicably has a genuine intention to compensate. There are a number of beneficiaries of this feature apart from the claimant - they include also public enforcers, who do not need to get involved at any stage to satisfy their objectives of compensation and deterrence. The same is not always achieved within a state enforcement system. Infringers often try to avoid final payments in all possible ways. There is no doubt that if the parties come to the table voluntarily, they also (usually) follow the final ruling/ decision/agreement, which is not the case after the proceedings before a state court. Therefore, consensual dispute resolution shall be - by all means - the preferred path.

Finally, some practitioners point at the lower cost argument. Unfortunately, this is not always the case. It may appear that arbitration needs less resources, but it may also turn out that the total cost will be higher compared with the cost of the 'state machinery'. This argument may also encourage the disputants to turn to a mediator, or to use completely informal negotiations, where the parties hold total control over their spending.

There are also disadvantages of arbitration used for the purpose of damage compensation. As the OECD rightly points out in its report (see Key Findings by Secretariat in OECD, 2010), some entrepreneurs may find arbitration: less transparent, less predictable (as there are scarce precedents available to the public), less effective in terms of investigation instruments available, and (sometimes) not enforceable. 
Although ADR may not be suitable for all cases, these methods of dispute resolution may often serve the parties far better compared to traditional litigation. ${ }^{16}$

\section{Directive's 'carrots' to enhance consensual resolution}

The Directive leaves no doubt that consensual resolution is a suitable instrument to settle discussed claims. In recital 48, it reads: 'Achieving a 'once-and-for-all' settlement for defendants is desirable in order to reduce uncertainty for infringers and injured parties' and 'the provisions in this Directive on consensual dispute resolution are therefore meant to facilitate the use of such mechanisms and increase their effectiveness'.

The Directive encompasses several instruments to encourage consensual settlement.

First, national laws should make sure that the statutory limitation is suspended during the time of consensual resolution. Second, the parties should have sufficient time if they decide to go for consensual resolution during the ordinary court proceedings. Third, an infringer who settles amicably should be 'protected' from further claims both: from the injured party or from its co-infringers.

\section{Suspension of the statutory limitation}

The drafters of the Directive were aware that time runs against potential claimants, and that the issue of time flow should be somehow reconciled with the desire to settle. Obviously, not all national proceedings recognised the same threshold for the suspension. In Polish substantive law, for instance, only arbitration or mediation would have an effect on the time-barring. Additionally, some of the legal systems would produce a different effect: for instance, engaging in some forms of ADR could result in stopping the clock (instead of suspending it).

The purpose of the Directive was to make every genuine effort to settle amicably, resulting in the suspension of the statutory limitation. This is being expressed under Article 18(1) of the Directive:

16 See: https://www.carteldamageclaims.com/compensation/settlements/ where the CDC specializing in claiming damages indicate 'multiple out-of-court' settlements in the cases in question (retrieved 23.07.2017). 
'Member States shall ensure that the limitation period for bringing an action for damages is suspended for the duration of any consensual dispute resolution process.

The suspension of the limitation period shall apply only with regard to those parties that are or that were involved or represented in the consensual dispute resolution'

The only practical issue that remains is to take care that the informal negotiations are sufficiently recorded, in order to be able to argue for the discussed suspension (as discussed earlier in this paper).

\section{Suspension during the court proceedings}

Usually, continental procedures indicate a preference for consensual resolution and contain various encouragements to settle out-of-court. In some systems, parties shall prove that before filing a claim with the court, they took reasonable efforts to resolve the dispute amicably. In others, the court has the duty to make sure that the dispute could not be resolved amicably, or to encourage the parties to negotiate. There are also various instruments the court may use: from fixing the time limit for coming up with an amicable solution to soft measures, such as signalising problems that could be better resolved between the parties themselves.

The Directive takes care that once the parties engage in negotiations during the court proceedings, the litigation will be effectively suspended for a time sufficient to settle outside the court. The Directive under Article 18(2) specifies that national legal systems should foresee up to a two years suspension during the court proceedings, if the parties indicate the wish to settle in an alternative manner.

\section{Modification of the settling infringer's liability in multi-party cases}

First of all, the Directive under Article 19 stipulates that the total amount of the damage will be effectively reduced by the relative part due from every infringer, despite actual compensation paid by the settling infringer. In other words, the settling infringer closes its case with the settling claimant, even if the settled amount is lower (which will be usually the case) than his relative share in the total damage amount.

Furthermore, under Article 19(2), the Directive protects the settling infringer against bringing the claim against him in another post-settlement proceeding. As it was rightly pointed out '[i]f a settling infringer were to continue to be fully jointly and severally liable for the harm caused, even after a consensual settlement was reached, it would be placed in a worse 
position compared to its co-infringers than it would otherwise be without the consensual settlement' (Wijckmans, Visser, Jacques and Noel, 2016, p. 780). However, when it comes to the principle of a full compensation, the Directive favours the interest of the party seeking compensation for damages. ${ }^{17}$ Namely, if this party may not - for any reason - recover the remaining part of the compensation from other (not-settling) infringers, it may still turn to the infringers with whom it settled its relative part(s). This rule may be excluded under the provision of the settlement itself. Thus, the settling party is fully protected only if the settlement itself provides for such full protection; otherwise, the settling party may still be challenged by the same claimant if the recovery of the remaining compensation proves ineffective. The question remains how the latter may be exercised. Most likely, the claimant will have to go through the entire proceeding, including execution proceedings, so that to evidence the ineffectiveness of the execution against other infringers. Thus, even without contractual protection, the settling party (defendant) may enjoy relative freedom from being too easily asked to pay additionally under the joint and several liability rule.

Moreover, the Directive protects the settling party (defendant) against reproach from other infringers (Article 19(2) of the Directive). In the ordinary course of business, if damage is paid by one defendant (under joint and several liability rule), such party may reproach other infringers and recover relative parts of the damage accordingly. The rule expressed under Article 19(2) of the Directive protects the settling party from being called to pay any additional compensation by co-infringers who did not settle with an injured party earlier.

The Directive under 19(4) protects a settling party with respect to compensating the damage to another injured entity. In essence, it requires national legislation to assure that the settling infringer (who may have voluntarily paid some part of the damage) will not pay in excess of its relative part when sharing the payment of the compensation with co-infringers vis-à-vis another injured entity with whom it did not settle amicably.

\section{Compensation as a fine mitigating factor}

Under Article 18(3) of the Directive 'A competition authority may consider compensation paid as a result of a consensual settlement and prior to its decision imposing a fine to be a mitigating factor'.

17 Under Art. 19(3) of the Directive: 'By way of derogation from paragraph 2, Member States shall ensure that where the non-settling co-infringers cannot pay the damages that correspond to the remaining claim of the settling injured party, the settling injured party may exercise the remaining claim against the settling co-infringer'. 
Public and private enforcement may come into conflict here. On one hand, NCAs desire to enhance deterrence through high fines. On the other hand, the fine shall be reduced due to the compensation paid by an infringer.

However, the contradiction seems rather artificial Effective damage claims have undoubtedly also a deterrent effect if potential infringers would - as a consequence of their breach of competition law - anticipate not only paying a fine but also compensating all the injured entities. Thus, the conflict does not exist, and both ways of enforcing competition law shall work in combination as deterring factors. The purpose of Article 18(3) is thus to establish another encouragement to settle and to make the fine paid as a result of the infringement, fair and proportional.

The fining policies of various Member States may vary on this issue, and therefore it is highly desirable to work out a common strategy within the EU. The example could actually come from the Commission that frequently inspired Member States to introduce certain legislation in different enforcement areas (leniency can serve as a success story). ${ }^{18}$ In the meantime, the Commission 2006 Fining Guidelines ${ }^{19}$ remain silent on the impact of compensation on a fine reduction. Although the Commission seems to encourage the payment of compensation either through an effective lowering of the fines (such as in General Motors, ${ }^{20}$ Pre-insulated Gas cartel $^{21}$ or Nintendo ${ }^{22}$ ) or closing the proceedings in an alternative way. The examples for the latter are: Macron, where the Commission closed the file after Angus Fire paid a compensation to the complainant Macron, and Sony/Philips (both cases are discussed by Ezrahi and Ioannidou, 2012, p. 541), where the Commission accepted commitments after Philips' payment of due amounts to its licensees; Deutsche Bahn ${ }^{23}$ is also a telling example here, where the Commission proposed commitments involving compensations to be paid to customers. The new proposal on empowering competition authorities with effective tools to enforce EU and

18 ECN Model Leniency Programme: 2012 revision, http://ec.europa.eu/competition/ecn/ mlp_revised_2012_en.pdf (retrieved 14.07.2017).

19 Guidelines on the method of setting fines imposed pursuant to Art. 23(2)(a) of Regulation No. $1 / 2003$, OJ C210/49.

20 Commission Decision of 19.12.1974, Case No. IV/28.851 General Motors Continental, OJ L29/14.

${ }^{21}$ Commission Decision of 21.10.1999, Case No. IV/35.691/E-4 Pre-Insulated Pipe Cartel, OJ L24/1.

22 Commission Decision of 30.10.2002, COMP/35.587, 35.706, 36.321 Nintendo, OJ L255/33.

23 Press release: 'Antitrust: Commission market tests commitments proposed by Deutsche Bahn concerning pricing system for traction current in Germany', 15.08.2013, IP/13/780, the case ended with a commitment decision (Commission Decision of 18.12.2013, COMP/AT.39678, 39731 Deutsche Bahn I/II, OJ C86/4) in December 2013, see: http://ec.europa.eu/competition/ antitrust/cases/dec_docs/39678/39678_2514_15.pdf (retrieved 14.07.2017). 
national competition laws ${ }^{24}$ is also silent on the impact of compensation on the amount of the fine.

It is interesting to note that in jurisdictions where private enforcement has developed so far (Kuijpers, Tiunenga, Wisking, Dietzel, Campbell, Fritzsche, 2015, p. 129-142), namely: UK, the Netherlands and Germany, public enforcers actively use their instruments to encourage compensations to injured parties. The OFT, for instance, reduced the fines imposed on independent schools who participated in a fee-setting cartel upon an ex gratia payment to an educational trust which 'benefited those who attended the schools in the relevant period'. ${ }^{25}$ Moreover, the German Bundeskartellamt closed its proceedings concerning two abuses of dominance due to compensations paid by the alleged abusers to their customers (OFT Decision No. CA98/05/2006 discussed by Ezrahi and Ioannidou, 2012, p. 540).

The described examples from the mentioned jurisdictions clearly indicate that public policy instruments used by NCAs can strongly encourage consensual settlement, and contribute to private compensation greatly. Those instruments are not limited to fine reductions. Obviously, in the given cases, the above NCAs resigned from imposing fines at all, favouring commitments or closing the file subject to compensating injured parties.

Another question that remains is whether compensation paid after a public enforcement decision could serve as an argument for a court to reduce the fine during the judicial review process of the decision issued by a NCA.

It seems that making it possible to raise such argument at the judicial review stage would be in line with the policy to encourage (as much as possible) voluntary compensation in general. This reasoning has actually driven the appellant in Nintendo ${ }^{26}$ to seek a further reduction of the fine imposed by the Commission in its decision against Nintendo. ${ }^{27} \mathrm{~A}$ further reduction by the Court was however denied on this ground (the Court did lower the fine on different grounds though) since the appellant was relying on the 'legitimate expectation' rule to argue for an even greater reduction than that actually granted by the Commission in its fining decision.

The Nintendo case reveals another problem: although it may be apparent for competition authorities to take into account compensation paid voluntarily

${ }^{24}$ Proposal for a Directive to empower the competition authorities of the Member States to be more effective enforcers and to ensure the proper functioning of the internal market, 22.03.2017, COM(2017) 142 final, http://ec.europa.eu/competition/antitrust/proposed_directive_ en.pdf (retrieved 14.07.2017).

25 Others give also another example from the UK practice: the Rover case where the OFT reduced the fine on Rover upon compensation paid to consumers and funds being contributed to the Consumer Association.

26 Judgment of 30.04.2009, T-13/03 Nintendo, ECLI:EU:T:2009:131.

27 Commission Decision of 30.10.2002, COMP/35.587, 35.706, 36.321 Nintendo, OJ L255/33. 
to the injured party, the extent of this reduction lies within the discretion of the competition authority. This uncertainty may work against voluntary compensations. In Nintendo for instance, the compensation paid by the infringer amounted to EUR 375,000 while the reduction granted to Nintendo equalled EUR 300,000. The appellant's complaint was that the fine reduction should be equal to the compensation paid; it further argued that Nintendo's representatives were given assurance to this effect by the Commission. The Court did not confirm the reasoning and kept the reduction (under this argument) at the level of EUR 300,000. The court in any case seemed receptive to the argument, since it did not deny raising the plea at the judicial review stage.

\section{Implementation of the Directive in the area of consensual resolution in CEE countries}

Many of the Member States have already implemented the Directive. ${ }^{28}$ The Polish act implementing the Directive came into force 27 June 2017. ${ }^{29}$ Legislative works are still in progress in a number of Member States.

Based on the detailed reports from a number of CEE countries (the publications covers: Bulgaria, Croatia, Czech Republic, Estonia, Hungary, Latvia, Lithuania, Poland, Romania, Slovakia and Slovenia, see Piszcz, 2017), the implementation of Article 18 and Article 19 of the Directive, including the definition of 'consensual dispute resolution', was smooth. However, there are a few exceptions. The Czech Republic's implementation failed to introduce a suspension of the limitation during any consensual dispute resolution process (Petr, 2017, p. 106). There in another interesting variation in Slovakia. The Slovak law implementing the Directive with respect to the impact of settling a part of the damage by one co-infringer provides for the reduction by the amount actually paid, instead of a reduction by the relative part irrespective of the part actually paid, as envisaged in the Directive (Blažo, 2017, p. 261).

The greatest diversity can be found in relation to the implementation of the Article 18(3) of the Directive, which requires the consideration, as a mitigating factor, of compensation paid as a result of a consensual settlement. In some CEE countries (Poland, Estonia, Slovenia), such provisions have already existed in the relevant national competition acts. In some others (Bulgaria,

28 As of 14 June 2017, 20 Member States reported their implementation of the Directive.

${ }^{29}$ Legislation is available in Polish at: http://isap.sejm.gov.pl/DetailsServlet?id= WDU20170001132 (retrieved 14.07.2017). 
Hungary, Lithuania, Slovakia and Romania), the relevant inclusions were made in order to implement the Directive. Croatia has made the choice not to regulate the matter explicitly, leaving it entirely to the competition authority's discretion or future regulation in the national competition act (Butorac Malnar, 2017, p. 81).

A summary of the implementation status in CEE countries is presented in the chart below: 30

\begin{tabular}{|l|c|c|c|c|}
\hline & $\begin{array}{c}\text { Suspension } \\
\text { of limitation period } \\
\text { during ADR }\end{array}$ & $\begin{array}{c}\text { Staying the court } \\
\text { proceedings during } \\
\text { ADR }\end{array}$ & $\begin{array}{c}\text { Effect } \\
\text { on fine }\end{array}$ & $\begin{array}{c}\text { Limitation } \\
\text { of joint and } \\
\text { several liability }\end{array}$ \\
\hline Bulgaria & $\mathrm{V}$ & $\mathrm{V}$ & $\mathrm{V}$ & $\mathrm{V}$ \\
\hline Croatia & $\mathrm{V}$ & $\mathrm{V}$ & $\mathrm{X}$ & $\mathrm{V}$ \\
\hline Czech Rep. & $\mathrm{X}$ & $\mathrm{V}$ & $\mathrm{IN}$ & $\mathrm{V}$ \\
\hline Poland & $\mathrm{V}$ & $\mathrm{V}$ & $\mathrm{IN}$ & $\mathrm{V}$ \\
\hline Estonia & $\mathrm{IN}$ & $\mathrm{V}$ & $\mathrm{IN}$ & $\mathrm{V}$ \\
\hline Hungary & $\mathrm{V}$ & $\mathrm{V}$ & $\mathrm{V}$ & $\mathrm{V}$ \\
\hline Latvia & $\mathrm{V}$ & $\mathrm{V}$ & $?$ & $\mathrm{~V}$ \\
\hline Lithuania & $\mathrm{V}$ & $\mathrm{V}$ & $\mathrm{V}$ & $\mathrm{V}$ \\
\hline Slovakia & $\mathrm{V}$ & $\mathrm{V}$ & $\mathrm{V}$ & $\mathrm{V}$ \\
\hline Romania & $\mathrm{V}$ & $\mathrm{V}$ & $\mathrm{V}$ & $\mathrm{V}$ \\
\hline
\end{tabular}

For symbols' explanation, please see footnote 30 .

\section{Claiming damages resulting from an infringement of competition law in a consensual way vs state court - post-Directive}

One may wonder whether consensual dispute resolution remains attractive once the Member States modify their procedures and substantive regulations in order to implement the Directive effectively. The answer is: in many instances, the disputing parties may still have a strong preference for an amicable and confidential resolution, since the facilitations introduced as a result of the Directive could be also partially or entirely achieved in arbitration.

30 Symbols indicate the following: $\mathrm{V}$ - implementation; $\mathrm{x}$ - no implementation; IN - existence of a given rule under national law; ? - means difficulty in establishing the actual status at the moment of closing of the article; and the situation in Slovakia marked as $\mathrm{V}^{*}$ has been explained in the body of the text. 
First, all substantive provisions covered in the Directive (and implemented in national laws) shall apply, provided this is the Member State's law which is applicable to a dispute at hand. Consequently, any tribunal or conciliator proceeding on the basis of the law of any Member State (that implemented the Directive) will need to apply the rules on joint and several liability as well as, on the passing-on and on indirect purchasers. The statutory limitation remains part of this set of rules as well.

The rules on the burden of proof are, however, problematic since they are regarded as substantive or procedural.

Second, although procedural facilitations will only be applicable before a state court, it seems that the outcome designed in the Directive (in the procedural dimension) could be reached by other means available in ADR. The best example is found in the disclosure of evidence (compare different view by Moisejevas, 2015, p. 190), which is key for successful claim settling.

In order to resolve asymmetry in access to documents, the IBA Rules on Taking Evidence in International Arbitration ${ }^{31}$ (frequently applied in international arbitration) address the issue and foresee under Article 3 a 'request to produce' necessary evidence. As a result of the application of those rules, the party refusing to produce certain documents could suffer adverse inferences to be drawn by the tribunal against the refusing party. Furthermore, although popular rules applied in arbitral proceedings, such as the UNCITRAL Arbitration Rules (as revised in 2010) ) $^{32}$ or ICC Rules of Arbitration (current as of 1 March 2017), ${ }^{33}$ are silent about similar 'discovery' procedures, nothing shall preclude the claimant from bringing the issue before the tribunal, which may order the other party to produce the relevant documents. In any case, the parties themselves may consensually decide to introduce regulations similar to those covered under Article 3 of IBA Rules or similar to those included in the Directive.

Another important facilitation is the binding force of the decisions issued by NCAs. In this case, it seems that arbitral tribunals will have a strong inclination to treat such decisions as prima faciae evidence and above all, will avoid discrepancy in view of their duty to respect public policy. ${ }^{34}$ The same reason may cause an arbitral tribunal to refuse reviewing a leniency

31 IBA, Rules on the Taking of Evidence in International Arbitration (2010), www.ibanet.org/ Publications/publications_IBA_guides_and_free_materials.aspx (retrieved 17.07.2017).

32 UNCITRAL, Arbitration Rules as revised in 2010, https://www.uncitral.org/pdf/english/ texts/arbitration/arb-rules-revised/arb-rules-revised-2010-e.pdf (retrieved 17.07.2017).

33 ICC, Rules of Arbitration, https://iccwbo.org/dispute-resolution-services/arbitration/rulesof-arbitration (retrieved 17.07.2017).

34 As explained in the paper, competition law qualifies as public policy regulation; a violation of public policy rules may cause an award to be set aside or to be refused enforceability; it is a basic duty of every arbitrator to secure validity and enforceability of the award. 
application or to accept the refusal to submit such an application without drawing adverse inference from it, in line with the prohibition covered in the Directive (Nazzini, 2017).

Furthermore, a party in arbitration is not precluded from using the Commission's guidelines on quantification of harm. ${ }^{35}$ What is even more important, once a party (or its expert) decides to follow the methodology contained therein, it would be rather difficult to challenge that methodology; thus, the use of the guidelines could be a natural choice in the strategy of a prospect claimant.

Finally, even if the procedural or substantive facilitations are achieved only partially, the advantages of arbitration in general counterbalance the listed facilitations still.

\section{Conclusion}

Consensual dispute resolution may be regarded as the third pillar of competition law enforcement, next to public enforcement and claim settlement before a state court. In order to develop this method of achieving compensation, many stakeholders shall combine their competences and measures to facilitate ADR, or other ways to resolve competition claims amicably. An example could be found in the organised and thoughtful manner in which ADR is promoted within the UK, ${ }^{36}$ which is obviously bringing about the desired outcome of increasing the number of compensations paid to injured parties (Hodges, 2014, p. 268-269 and 284). Based on the UK example, it is apparent that for many reasons (many of them being listed in this paper) consensual dispute resolution of the claims in question will always be desirable from the perspective of the injured parties.

35 Communication from the Commission on quantifying harm in actions for damages based on breaches of Article 101 or 102 of the Treaty on the Functioning of the European Union, 2013/C 167/07 http://eur-lex.europa.eu/LexUriServ/LexUriServ.do?uri=OJ:C:2013:167:0019:00 21:EN:PDF (retrieved 14.07.2017); Practical Guide Quantifying Harm In Actions For Damages Based On Breaches Of Article 101 or 102 Of The Treaty On The Functioning of the European Union, http://ec.europa.eu/competition/antitrust/actionsdamages/quantification_guide_en.pdf (retrieved 14.07.2017).

36 See: UK government Department for Business, Innovation and Skills, Private actions in competition law: a consultation on options for reform, https://www.gov.uk/government/ uploads/system/uploads/attachment_data/file/31528/12-742-private-actions-in-competition-lawconsultation.pdf (retrieved 14.07.2017). 


\section{Literature}

Bellinghausen, R. and Grothaus, J. (2015). The CJEU's Decision in CDC v AKZO NOBEL et al. Cartel: a Blessing or a Curse for Arbitrating Cartel Damage Claims, Kluwer Arbitration Blog. Retrieved from: http://kluwerarbitrationblog.com/2015/07/31/ the-cjeus-decision-in-cdc-v-akzo-nobel-et-al-a-blessing-or-a-curse-for-arbitrating-carteldamage-claims/ (20.07.2017).

Blažo, O. (2017). Slovakia. In: A. Piszcz (ed.), Implementation of the EU Damages Directive in Central and Eastern European Countries. Warsaw: University of Warsaw, Faculty of Management Press.

Butorac Malnar, V. (2017). Croatia. In: A. Piszcz (ed.), Implementation of the EU Damages Directive in Central and Eastern European Countries. Warsaw: University of Warsaw, Faculty of Management Press.

Derains, Y. (2001). Specific Issues Arising in the Enforcement of EC Antitrust Rules by Arbitration Courts. In: C. Ehlerman, I. Atanasiu (eds), European Competition Annual 2001: Effective Private Enforcement of EC Antitrust Law. Oxford, Hart Publishing.

Ezrahi, A. and Ioannidou, M. (2012). Public compensation as a Complementary Mechanism to Damage Actions: From Policy Justifications to Formal Implementation, Journal of European Competition Law \& Practice, 3(6), 536-544.

Goldsmith, A. (2015). Arbitrating Antitrust Follow-on Damage Claims: a European Perspective (Part 1). Kluwer Arbitration Blog. Retrieved from: http://kluwerarbitration blog.com/2015/09/22/arbitrating-antitrust-follow-on-damages-claims-a-european-perspe ctive-part-1/ (20.07.2017).

Hodges, Ch. (2014). Fast, Effective and Low Cost Redress: How Do Public and Private Enforcement and ADR Compare. In: B. Rodger (ed.) Competition Law. Comparative Private Enforcement and Collective Redress Across the EU, Kluwer Law International.

Idot, L. (2010). Arbitration and Competition. In: OECD Report Competition Law and Policy, http://www.oecd.org/competition/abuse/49294392.pdf (14.07.2017)

Kolber, J. (2012). Zasady stosowania prawa konkurencji Unii Europejskiej przez sądy arbitrażowe, Kwartalnik ADR, 3(19), 67-81.

Kuijpers, M., Tiunenga, S., Wisking, S., Dietzel, K., Campbell, S. and Fritzsche, A. (2015). Actions for Damages in the Netherlands, the United Kingdom, and Germany, Journal of European Competition Law \& Practice, 6(2), 129-142.

Moisejevas, R. (2015). The Damages Directive and Consensual Approach to Antitrust Enforcement, Yearbook of Antitrust and Regulatory Studies, 8(12), 181-194.

Nazzini, R. (2017). Arbitration, Competition Law and the EU Directive, published on www. uianet.org (21.07.2017)

OECD. (2010). Arbitration and Competition, Paris: Organisation for Economic Co-operation and Development. Retrieved from: http://www.oecd.org/competition/abuse/49294392. pdf (14.07.2017).

Pavelka, T. (2012). Antitrust Arbitration Review. The Czech Do It Differently: but how much?, available at: https://papers.ssrn.com/sol3/papers.cfm?abstract_id=2166073 (17.07.2017).

Petit, N. (2014). The Principles of Equivalence and Effectiveness as a Limit to National Procedural Autonomy, Paper delivered at ENTraNCE 2014. Retrieved from: https:/ /antitrustlair.files.wordpress.com/2014/07/the-principles-of-equivalence-and-effective ness-n-petit-final.pdf (17.07.2017). 
Petr, M. (2017). Czech Republic. In: A. Piszcz (ed.), Implementation of the EU Damages Directive in Central and Eastern European Countries. Warsaw: University of Warsaw Faculty of Management Press.

Piszcz, A. (ed.) (2017). Implementation of the EU Damages Directive in Central and Eastern European Countries. Warsaw: University of Warsaw Faculty of Management Press.

Szpunar, M. (2010). Stosowanie prawa konkurencji Unii Europejskiej przez sądy arbitrażowe. In: J. Okólski (ed.), Księga pamiątkowa 60-lecia Sądu Arbitrażowego prze Krajowej Izbie Gospodarczej w Warszawie, Warszawa, Sąd Arbitrażowy.

Wijckmans, F., Visser, M., Jacques, S. and Noel, E. (2016). The EU Private Damages directive - Practical Insights. Minutes of the Closed Workshop 2015, Antwerpen, Intersentia.

Živković, P. (2017). Antitrust Arbitration in Europe (Part II): Improving Private Enforcement by Removing Procedural and Evidential Barriers in Arbitration. Kluwer Arbitration Blog. Retrieved from: http://kluwerarbitrationblog.com/2017/06/03/antitrustarbitration-europe-part-ii-scope-effect-arbitration-clauses-microsoft-case/ (20.07.2017). 